\title{
Young Adult Perspectives on a Successful Transition from Pediatric to Adult Care in Sickle Cell Disease
}

\section{Citation}

Sobota, Amy E., Emeka Umeh, and Jennifer W. Mack. 2016. “Young Adult Perspectives on a Successful Transition from Pediatric to Adult Care in Sickle Cell Disease." Journal of hematology research 2 (1): 17-24. doi:10.12974/2312-5411.2015.02.01.3. http:// dx.doi.org/10.12974/2312-5411.2015.02.01.3.

\section{Published Version}

doi:10.12974/2312-5411.2015.02.01.3

\section{Permanent link}

http://nrs.harvard.edu/urn-3:HUL.InstRepos:27320299

\section{Terms of Use}

This article was downloaded from Harvard University's DASH repository, and is made available under the terms and conditions applicable to Other Posted Material, as set forth at http:// nrs.harvard.edu/urn-3:HUL.InstRepos:dash.current.terms-of-use\#LAA

\section{Share Your Story}

The Harvard community has made this article openly available.

Please share how this access benefits you. Submit a story.

Accessibility 
Published in final edited form as:

J Hematol Res. 2015 December ; 2(1): 17-24. doi:10.12974/2312-5411.2015.02.01.3.

\title{
Young Adult Perspectives on a Successful Transition from Pediatric to Adult Care in Sickle Cell Disease
}

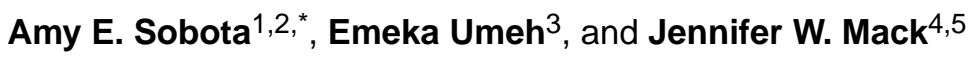 \\ ${ }^{1}$ Boston University School of Medicine, Boston, MA \\ ${ }^{2}$ Boston Medical Center, Department of Pediatrics, Boston, MA \\ ${ }^{3}$ Boston University School of Public Health, Boston, MA \\ ${ }^{4}$ Dana-Farber/Boston Children's Cancer and Blood Disorders Center, Boston, MA \\ ${ }^{5}$ Harvard Medical School, Boston, MA
}

\section{Abstract}

Objective-This qualitative study sought to learn from young adults with sickle cell disease (SCD) about their experience leaving pediatric care and perspective on what makes a successful transition.

\begin{abstract}
Methods-Fifteen young adults with SCD who had left pediatric care within the previous five years participated in focus groups led by a trained moderator. Transcripts were analyzed using grounded theory.

Results-Four main themes emerged from the analysis: facilitators of transition (meeting the adult provider prior to transfer, knowing what to expect, gradually taking over disease selfmanagement and starting the process early), barriers to transition (negative perceived attitude of adult staff, lack of SCD specific knowledge by both patients and staff, and competing priorities interfering with transition preparation), what young adults wished for in a transition program (opportunities to meet more staff prior to transfer, more information about the differences between pediatric and adult care, learning from a peer who has been through the process, more SCD teaching, and flexibility in transition preparation) and how they define a successful transition (gradually assuming responsibility for self-management of their SCD).
\end{abstract}

Conclusion-Our findings present unique opportunities to learn from young adults with SCD about ways to improve current transition programs.

\section{Keywords}

Sickle cell disease; transition; adolescents

This is an open access article licensed under the terms of the Creative Commons Attribution Non-Commercial License (http:// creativecommons.org/licenses/by-nc/3.0/) which permits unrestricted, non-commercial use, distribution and reproduction in any medium, provided the work is properly cited.

"Address correspondence to this author at the 850 Harrison Avenue, Yawkey Ambulatory Care Center 4S-11, Boston, MA 02118; Tel: (617) 414-5562; Fax: (617) 414-5597; amy.sobota@bmc.org.

Conflicts of Interest: None of the authors have any conflicts of interest to report. 


\section{Introduction}

Sickle cell disease (SCD) is an inherited blood disorder affecting approximately 100,000 people in the US, mainly those of African American descent [1]. Improved medical care, such as widespread use of penicillin prophylaxis and pneumococcal vaccination, have led to a decline in childhood mortality in SCD [2]. These patients are now facing the need to transition to adult care. Data suggests that this time of transition is associated with increased health care utilization and risk of early mortality [2-4]. Specifically transition aged young adults have higher rates of ED utilization, ED reliance, and hospitalization compared with both younger and older patients $[5,6]$.

In order to improve these outcomes, programs are being developed to better prepare youth with SCD for a successful transition [7]. In studies of pre-transition adolescents, patients with SCD have expressed concerns about not having enough information about transition, worries about leaving a familiar system and trusted provider, concern that adult providers may not know them or their disease, and general anxiety over changing family roles as they enter adulthood [8-10]. Much less is known about the feelings of young adults after they have left pediatrics and established themselves in the adult care system [11]. We sought to learn from young adults with SCD who had recently transferred from pediatric to adult care about their experience, what had helped them in the transition process and what they saw as a successful transition in order to improve transition preparation and outcomes in this high risk population.

\section{Materials and Methods}

\subsection{Study Design}

We held focus groups with young adults with SCD to learn what their transition experience had been and what they would like to see improved. We chose to use focus groups in order to explore in depth the experiences of young adults, to generate hypotheses for future work and because we felt the interactions between participants would enrich the data collected [12]. The Boston University Institutional Review Board approved this study.

\subsection{Eligibility}

Patients were eligible to participate if they had received care for SCD in the pediatric hematology clinics at Boston Medical Center (BMC) or Boston Children's Hospital (BCH) and had left pediatric care within the past 5 years, which is how long the BMC transition clinic has been in existence. Patients were eligible whether or not they were currently being seen in an adult clinic and regardless of the degree of transition preparation they had received. Because we sought patients who had left pediatric care within the previous 5 years, and this usually occurs by age 22 we recruited patients between the ages of 18 and 28 . There were a total of 77 potentially eligible patients identified at $\mathrm{BMC}$ and 15 from $\mathrm{BCH}$.

\subsection{Recruitment}

We used multiple methods to recruit patients. Letters were sent directly to patients from BMC describing the project and providing contact information for study personnel so that 
eligible patients could either opt in or opt out of participating. If no opt-out message was received within two weeks, research staff called patients to ask if they wished to participate. Up to three attempts were made to contact patients unless they declined to participate. Patients from $\mathrm{BCH}$ were not contacted directly by BMC research staff due to privacy issues. Instead stamped envelopes containing information about the project and contact information for study personnel were provided to clinicians at $\mathrm{BCH}$ who then addressed and mailed packets to eligible patients.

\subsection{Focus Group Sessions}

Focus group sessions were held at BMC and lasted approximately two hours. Three focus groups were initially planned over a one month period, and a fourth one was added two weeks later because thematic saturation was not reached after the first three. The focus groups were moderated by a trained moderator with extensive experience in qualitative research methods and experience with focus groups from diverse populations. A research assistant (RA) was present at each group as an observer and note taker. No member of the health care team was present during the focus groups due to potential bias. Each participant completed an anonymous demographics questionnaire asking about transition preparation and timing of transfer, provided informed consent, and was compensated with a $\$ 50 \mathrm{gift}$ card for their time as well as travel expenses.

\subsection{Discussion Guide}

We developed an initial focus group guide based on existing literature on transition as well as the experience of the principal investigator (PI) [13]. The guide was modified following individual review by colleagues with expertise in transition or SCD. Questions and probes were used by the moderator to lead the discussion. Topics addressed included the following: description of participants' transition experience, what helped them during the process, how to define success of transition, looking back what they wished they had known, and any advice they would give on improving transition (Table 1). After each focus group the research team held a debriefing to determine if any modifications needed to be made in the guide. No significant changes were made as a result of this process. Each focus group was audiotaped and transcribed by a professional company and the transcript was reviewed for errors by the focus group moderator.

\subsection{Data Analysis}

Analysis was done independently by two teams; team 1 consisted of the focus group moderator, who was hired specifically because of his experience in conducting qualitative research, and group 2 included the PI and RA (AS and EU). Each team reviewed the transcripts as well as notes taken during each session to clarify and confirm elements of the transcripts. Each team then coded the data separately using grounded theory for the analysis, which allows themes to emerge from the data [14]. Codes were reviewed by each team for consistency. The initial open codes were further analyzed and grouped according to themes to reach a final analysis. The findings of each group were compared by the PI; no significant discrepancies were found. 


\section{Results}

\subsection{Participants}

Fifteen patients took part in four focus group sessions. The mean age at the time of the study was 24.2 years, $53 \%$ were female. Participants reported leaving pediatric care at a mean age of 21.2 years. Most participants (77\%) reported some preparation for transition (Table 2).

Themes on the transition from pediatric to adult care emerged from the analysis in four main categories; facilitators of transition, barriers to transition, what participants wished they had known, and how they defined a successful transition.

\section{Facilitators of Transition}

\subsection{Familiar Clinic Provider}

Participants from BMC who had met the adult hematology provider during transition clinic visits believed this was helpful in facilitating their transition to adult care.

"getting to know their new provider, too, is something that is very useful in a transition, because you want to feel comfortable with the provider that you have, so that you can open up to them and speak to them, just like you would to your pediatric provider."

\subsection{Knowing What to Expect}

In general patients valued in having detailed information about what to expect from transition; everything from who they were going to see to what the registration process would be like. Participants emphasized a desire 'not to be surprised' after transition.

"All the differences or changes between pediatrics and adult care, and try to inform the patients on everything as much as possible so there's as little surprises as there can be."

\subsection{Transition Preparation}

Both the transition clinic at BMC and the transition guidebook we developed for our patients were felt to be helpful in transition preparation.

"The Transition Clinic really helps...by getting familiar with your new doctor"

\subsection{Gradually Assuming Self-Management of SCD}

Participants commented on how they had become responsible for their own disease selfmanagement as they got older. In some cases their parents helped this process by gradually giving the young adult more responsibility, and this was reported as favorable by participants.

"I was very reliant on my mom.......... And then when I went to college, it was, like, it was different because she had to like step back, so, I would just do it on my own.... But, I felt that she did the right thing by stepping back, because had she not, then I wouldn't have had to step forward and do things on my own. So, she knew what she had to do, which was good for me now, because now I do everything on 
my own and I know I can take care of myself and I know how to be an adult patient."

\subsection{Starting Discussion Early}

Most of the group also endorsed the importance of starting the process early:

"I think that a successful transition that's introduced, like, earlier than later?

Because I think it's easier, if you're planning for it, well before it happens."

\section{Barriers to Transition}

\subsection{Negative Interactions with Adult Providers}

Almost all of the participants remarked on the perceived negative attitude of adult providers, specifically in the emergency department (ED) and when admitted. Many participants felt they were not believed when they presented to the ED with pain or felt they were treated as drug seekers. Several participants felt that their pain level was not believed because of their affect. Overall they reported a perception that adult providers were not as 'caring' as their pediatric providers had been.

"you'll come in, in a lot of pain. Like it's a 10, but I'm not cryin' like a little girl. But, so they just leave you there for an hour, and then they get frustrated that you have an attitude. Of course I have an attitude."

"I'm here to get help. If I wanted drugs, um, the "hood is down the street."

\subsection{Lack of SCD Knowledge}

Participants reported that they did not have enough knowledge about their own disease at the time of transition. Many participants also said that adult staff members, specifically in the ED and inpatient units, were not well informed about SCD.

"When I was a kid I just though sickle cell was like...you just get pain..... But, it's really WAY MORE to that."

"I think the first time we went to the floor... a couple nurses... So, she was like, 'Well, we don't know much about sickle cell over here,"'

\subsection{Competing Priorities}

Several participants also commented on the fact that transition preparation was not a priority for them at the time, but in retrospect was helpful.

"it was annoying to me because I felt.... like, it was kind of unnecessary. But, overall, I think I am happy I did go. But, like, at that time... because I'm like a lastminute person, I don't really like thinking about the future. but ... now I appreciate it" 


\section{What They Would Have Liked}

\subsection{More Information about Differences between Pediatric and Adult Care}

While patients valued the information they learned in transition clinic, they wanted more information on what to expect, specifically on the differences in the experience between pediatric and adult care.

"I feel like I wasn't 100\% prepared... while they talked about some aspects that came with adult care they didn't prepare me for EVERYTHING"

\subsection{Meeting Staff in the ED/Inpatient Prior to Transfer}

Several participants mentioned wishing they had been able meet adult ED/inpatient staff prior to transfer.

"I think that (prior interaction with adult patients' nurses) would be, probably the... what would help me the most."

\subsection{Hearing from Someone who has Gone through the Transition Process}

Participants also said it would have been valuable to have heard from an adult patient prior to transition.

"I think it would be nice if they had somebody who had already transitioned, to talk about how their transition was. Because it's different, having somebody who is telling you how it's going to be, or what to expect, and then somebody who... you know, dealt with it and can tell you exactly their experience."

\subsection{More Knowledge about SCD}

"I just wish that these doctors... would like just give you more information on your disease and what it can do to you."

\subsection{More Emphasis on Importance of Transition Preparation}

A few participants commented that they found transition clinic 'annoying', but in retrospect those who had participated in a transition program felt it allowed them to be better prepared. Most of the group wished they had been 'pushed' to attend transition clinic, several even saying it should be 'mandatory'.

"I think more information about the transition clinic, like, maybe having your doctor tell you about that, or... tell you WHY it's, it's good. Because, looking back, it, it would have been helpful."

\subsection{More Flexibility in Scheduling Transition Clinic}

Scheduling flexibility would also have helped these young adults.

"I know when they had it, when I was there, I wasn't able to attend. But, I would have, if, like, they had more options." 


\section{Transition Success}

\subsection{Managing your Own Disease}

When asked about what makes transition a success, over and over again participants commented on the importance of managing their own disease. Participants felt that developing personal responsibility for their disease was a mark of transition success.

"you're doing what you're supposed to be doing and your mom don't have to bug you about it"

\subsection{Self-Management Happen all at Once}

However several mentioned that they went through 'a rough patch' when they took first over responsibility and that it was not always easy to make things work well. They also stressed that this is a process that takes time and acknowledged the inevitability of growing up.

"it's kind of like a, a rough patch, when you first start taking care of like, your own meds and your own, like, filling up your prescriptions and go pickin' 'em up and stuff like that... Sometimes you almost lay off it a little bit at first.. and then you have to have this... inconvenient talk with your doctor about WHY you need to take your meds then after a while you get used to it and you get, like, you get yourself scheduled and you know when to order your meds and when to pick them and make sure you never ran, run out of 'em, and stuff like that, you know. Remember to take them, and stuff like that,"

\section{Discussion}

Our study highlights the experiences of young adult with SCD as they transition from pediatric to adult care and assume more personal responsibility for their disease management. This work is important in adding the voice of post-transition young adults to the existing literature which mainly focuss on pre-transition adolescents and their concerns. Our current transition process, like that used by others, includes education about their disease, discussion of the adult system, and a chance to meet their adult clinic provider prior to transfer [15]. These aspects were clearly identified as important by members of our focus groups. However participants in our study also mentioned several novel factors that they felt would have benefited them in their transition to adult care. We can use these recommendations to better design our transition preparation processes, improve the care young adults receive, and think critically about how we measure transition success.

One novel finding is the desire expressed by young adults to meet ED or inpatient staff prior to transfer of care. The fear of leaving a familiar provider is a common theme in research of adolescents with chronic disease [16,17], with some studies suggesting that meeting their adult provider before transfer may facilitate patient's post transfer access to care $[15,18]$. However these studies focus almost exclusively on the outpatient clinic provider. Given that patients with SCD often require acute care, it is perhaps not surprising that having a chance to become familiar with the acute care setting and personnel would be helpful in alleviating some of the stress around transition. 
Focus group participants also wished they had a greater understanding of SCD. We previously showed that pre-transition adolescents with SCD lack disease specific knowledge [19], and our current work shows that this remains an issue even after transfer to adult care. The AAP and other groups recommend having patients be seen without a parent in the room for part of the visit starting at age 13 [20]. This practice may provide a good opportunity for providers to engage directly with adolescents and offer them disease specific teaching [21, 22].

Our findings emphasize that the current format of transition preparation is not meeting the needs of young adults who have many competing priorities. Our transition guidebook, which patients can review on their own time, was well received by the participants in this study [23] indicating that asynchronous methods of learning may be better suited to young adult patients.

In addition to disease specific knowledge, a crucial aspect of transition preparation is training in self-management skills [24-26]. Adolescence has been shown to be a time of poor adherence to therapy in other chronic diseases [27, 28]. Our focus group participants recognized this as well, reporting that prior to transition a parent or grandparent had been largely responsible for their medical care. Other work has explored the role parents play in disease management and transition preparation, which is an often overlooked part of the transition process [10]. Starting an adult model of care for patients at age 18 even if there is not a transfer of providers at this age, is one way to allow young adult patients to take over their own care while still under the more protective environment of pediatrics [20].

Unfortunately we know that the perceived negative attitude of ED providers towards patients with SCD is a barrier to care in this population [29]. This may stem from the fact that a very small subset of SCD patients are 'super utilizers' of the ED and inpatient services [30] which may affect the way in which ED and inpatient staff see all SCD patients [31]. Unfortunately almost all of the participants in our study had encountered this as well. Most of them shared stories about being labeled as 'drug seeking' or not being believed when they were in pain. Our study participants often commented about feeling that their more stoic affect (e.g. not crying from pain) was a reason they were not believed. We know there are racial disparities in pain treatment, so it's important to consider if cultural differences or racial discordance between patients and providers may be playing a role in this attitude [32]. More training must be done, especially with adult staff, to change this type of interaction and ensure that prejudice does not lead to poor care [29].

Overall our participants felt that medical staff lacked knowledge about SCD. Other studies have likewise shown that provider lack of knowledge is an additional barrier to optimal treatment of SCD [33]. Provider education should be pursued to ensure that all staff taking care of patients with SCD are knowledgeable about the disease.

Another potential solution to both provider knowledge and attitude is a dedicated sickle cell day hospital, which has been shown to reduce admissions and length of stay [34-37]. Since we know that having familiar providers is a facilitating factor for transition, the availability 
of a day hospital for young adult patients with SCD might very well help with their transition to adult care.

Another gap in our knowledge of transition is what constitutes success. In sickle cell disease certain health outcomes such as mortality or utilization rates such as unnecessary ED visits or hospitalizations have been proposed as signs of a poor transition, whereas attending a single clinic session with an adult provider is considered success [38]. The young adults in our study gave a new perspective on transition, focusing on disease self-management rather than health care utilization. Their reflections on needing to become independent in managing their disease, and having their parents gradually relinquish control, are crucial as we seek to measure the quality of transition programs. Patients reflected that they improved their selfmanagement over time, therefore the transition process may need to continue past that first adult clinic appointment to help patients learn disease self-management while still being supported.

There are limitations to our findings. Perhaps most importantly the participants who were motivated enough to attend a focus group session may be more motivated overall than patients who did not, which may mean they were also more likely to attend transition clinic and have a more successful transition. We attempted to reach patients who were not established in adult hematology care, however more work to include the voices of these patients would enrich our findings. Despite this however, our group overall identified many barriers to transition, so even if they were the more successful group there is still much to be learned from their experience. Our study also only included participants from two urban academic centers in the same city, so results may not be generalizable to all populations. This is the case with most qualitative work. However we believe many of the issues raised here would be salient to other programs.

These data suggest that further improvements in the transition process are needed and illustrate important considerations from the point of view of young adults who have already transferred care. However much more work need to be done to prepare patients, and improve the medical system, to provide optimal are for young adults with SCD during this vulnerable time. Novel approaches such as a peer mentoring program or web-based intervention may reach more patients compared with the traditional clinic approach. Important next steps include further education for patients and adult providers, ensuring adequate transition planning for youth and their families, and research to determine what factors have the most significant impact on transition quality.

\section{Acknowledgments}

Source of Funding: Dr. Sobota's work was funded through the Harvard Blood Scholars Career Development Program K12 grant (PI Neufeld).

\section{References}

1. Brousseau DC, Panepinto JA, Nimmer M, et al. The number of people with sickle-cell disease in the United States: national and state estimates. Am J Hematol. 2010; 85:77-78. serial online. [PubMed: 20029951] 
2. Quinn CT, Rogers ZR, McCavit TL, et al. Improved survival of children and adolescents with sickle cell disease. Blood. 2010; 115:3447-3452. serial online. http://dx.doi.org/10.1182/ blood-2009-07-233700. [PubMed: 20194891]

3. Brousseau DC, Owens PL, Mosso AL, et al. Acute care utilization and rehospitalizations for sickle cell disease. JAMA. 2010; 303:1288-1294. serial online. http://dx.doi.org/10.1001/jama.2010.378. [PubMed: 20371788]

4. Hassell KL. Population estimates of sickle cell disease in the U.S. Am J Prev Med. 2010; 38:S51221. serial online. [PubMed: 20331952]

5. Hemker BG, Brousseau DC, Yan K, et al. When children with sickle-cell disease become adults: lack of outpatient care leads to increased use of the emergency department. Am J Hematol. 2011; 86:863-865. serial online. http://dx.doi.org/10.1002/ajh.22106. [PubMed: 21815184]

6. Blinder, MA.; Vekeman, F.; Sasane, M., et al. Age-related treatment patterns in sickle cell disease patients and the associated sickle cell complications and healthcare costs. Pediatr Blood Cancer. 2013. serial onlinehttp://dx.doi.org/10.1002/pbc.24459

7. Sobota A, Neufeld EJ, Sprinz P, et al. Transition from pediatric to adult care for sickle cell disease: results of a survey of pediatric providers. Am J Hematol. 2011; 86:512-515. serial online. http:// dx.doi.org/10.1002/ajh.22016. [PubMed: 21594889]

8. Telfair J, Ehiri JE, Loosier PS, et al. Transition to adult care for adolescents with sickle cell disease: results of a national survey. Int J Adolesc Med Health. 2004; 16:47-64. serial online. http:// dx.doi.org/10.1515/ijamh.2004.16.1.47. [PubMed: 15148858]

9. Telfair J, Myers J, Drezner S. Transfer as a component of the transition of adolescents with sickle cell disease to adult care: adolescent, adult, and parent perspectives. J Adolesc Health. 1994; 15:558-565. serial online. http://dx.doi.org/10.1016/1054-139X(94)90139-T. [PubMed: 7857954]

10. Porter JS, Graff JC, Lopez AD, et al. Transition from pediatric to adult care in sickle cell disease: perspectives on the family role. J Pediatr Nurs. 2014; 29:158-167. serial online. http://dx.doi.org/ 10.1016/j.pedn.2013.10.002. [PubMed: 24188784]

11. Bryant R, Young A, Cesario S, et al. Transition of chronically ill youth to adult health care: experience of youth with hemoglobinopathy. J Pediatr Health Care. 2011; 25:275-283. serial online. http://dx.doi.org/10.1016/j.pedhc.2010.02.006. [PubMed: 21867855]

12. Krueger, RA.; Casey, MA. Focus Groups: A Practical Guide for Applied Research. SAGE Publications, Inc; 2008.

13. Got Transition TM/Center for Health Care Transition Improvement. [Accessed July 31, 2014] Transitioning Youth to An Adult Health Care Provider. Six Core Elements of Health Care Transition 2.0. 2014. Available at: http://gottransition.org/resourceGet.cfm?id=220

14. Suddaby R. From the Editors: What Grounded Theory is Not. Acad Mange J. 2006; 49:633-642. http://dx.doi.org/10.5465/amj.2006.22083020.

15. Hankins JS, Osarogiagbon R, Adams-Graves P, et al. A transition pilot program for adolescents with sickle cell disease. J Pediatr Health Care. 2012; 26:e45-9. serial online. http://dx.doi.org/ 10.1016/j.pedhc.2012.06.004. [PubMed: 22819193]

16. Anie KA, Telfair J. Sickle Cell Disease Transition Study Working Group. Multi-site study of transition in adolescents with sickle cell disease in the United Kingdom and the United States. Int J Adolesc Med Health. 2005; 17:169-178. serial online. http://dx.doi.org/10.1515/ijamh. 2005.17.2.169. [PubMed: 15971736]

17. McPherson M, Thaniel L, Minniti CP. Transition of patients with sickle cell disease from pediatric to adult care: Assessing patient readiness. Pediatr Blood Cancer. 2009; 52:838-841. serial online. http://dx.doi.org/10.1002/pbc.21974. [PubMed: 19229973]

18. Bloom SR, Kuhlthau K, Van Cleave J, et al. Health care transition for youth with special health care needs. J Adolesc Health. 2012; 51:213-219. serial online. http://dx.doi.org/10.1016/ j.jadohealth.2012.01.007. [PubMed: 22921130]

19. Sobota, A.; Akinlonu, A.; Champigny, M., et al. Self-reported Transition Readiness Among Young Adults With Sickle Cell Disease. J Pediatr Hematol Oncol. 2014. serial onlinehttp://dx.doi.org/ 10.1097/MPH.0000000000000110

20. American Academy of Pediatrics, American Academy of Family Physicians, American College of Physicians. et al. Supporting the health care transition from adolescence to adulthood in the 
medical home. Pediatrics. 2011; 128:182-200. serial online. http://dx.doi.org/10.1542/peds. 2011-0969. [PubMed: 21708806]

21. Bryan, R.; Porter, JS.; Sobota, AE. APHON/ASPHO Policy Statement for the Transition of Patients with Sickle Cell Disease from Pediatric to Adult Health Care. 2014. Available at: http:// www.aphon.org/files/public/SCD_transition_final_draft.pdf

22. Jane Hankins and the WISCH Transition Affinity Group. [Accessed July 15th, 2014] Recommended Curriculum for Transition from Pediatric to Adult Medical Care for Adolescents with Sickle Cell Disease: Suggested Topics, Methods, and Efficacy Measurements. 2013. Available at: http://www.nichq.org/stories/SickleCellTransitionCurriculum.pdf

23. Boston Medical Center. Sickle Cell Disease Transition Guidebook. 2012. Available at: http:// www.nepscc.org/NewFiles/Transitionguidebook2012.pdf

24. Reiss J, Gibson R. Health care transition: destinations unknown. Pediatrics. 2002; 110:1307-1314. serial online. [PubMed: 12456950]

25. Hankins JS, Osarogiagbon R, Adams-Graves P, et al. A transition pilot program for adolescents with sickle cell disease. J Pediatr Health Care. 2012; 26:e45-9. serial online. http://dx.doi.org/ 10.1016/j.pedhc.2012.06.004. [PubMed: 22819193]

26. Andemariam B, Owarish-Gross J, Grady J, et al. Identification of risk factors for an unsuccessful transition from pediatric to adult sickle cell disease care. Pediatr Blood Cancer. 2014; 61:697-701. serial online. http://dx.doi.org/10.1002/pbc.24870. [PubMed: 24347402]

27. Fair CD, Sullivan K, Gatto A. Indicators of transition success for youth living with HIV: perspectives of pediatric and adult infectious disease care providers. AIDS Care. 2011; 23:965970. serial online. http://dx.doi.org/10.1080/09540121.2010.542449. [PubMed: 21390882]

28. Garvey KC, Markowitz JT, Laffel LM. Transition to adult care for youth with type 1 diabetes. Curr Diab Rep. 2012; 12:533-541. serial online. http://dx.doi.org/10.1007/s11892-012-0311-6. [PubMed: 22922877]

29. Freiermuth CE, Haywood C Jr, Silva S, et al. Attitudes toward patients with sickle cell disease in a multicenter sample of emergency department providers. Adv Emerg Nurs J. 2014; 36:335-347. serial online. http://dx.doi.org/10.1097/TME.0000000000000036. [PubMed: 25356894]

30. Jiang, H.; Barrett, M.; Sheng, M. Characteristics of Hospital Stays for Nonelderly Medicaid SuperUtilizers, 2012 HCUP Statistical Brief \# 184. Nov. 2014 Available at: http://www.hcupus.ahrq.gov/reports/statbriefs/sb184-Hospital-Stays-Medicaid-Super-Utilizers-2012.jsp

31. Carroll CP, Haywood C Jr, Fagan P, et al. The course and correlates of high hospital utilization in sickle cell disease: Evidence from a large, urban Medicaid managed care organization. Am J Hematol. 2009; 84:666-670. serial online. http://dx.doi.org/10.1002/ajh.21515. [PubMed: 19743465]

32. Tait RC, Chibnall JT. Racial/ethnic disparities in the assessment and treatment of pain: psychosocial perspectives. Am Psychol. 2014; 69:131-141. serial online. http://dx.doi.org/ 10.1037/a0035204. [PubMed: 24547799]

33. Haywood C Jr, Beach MC, Lanzkron S, et al. A systematic review of barriers and interventions to improve appropriate use of therapies for sickle cell disease. J Natl Med Assoc. 2009; 101:10221033. serial online. [PubMed: 19860302]

34. Lanzkron, S.; Carroll, CP.; Hill, P., et al. Impact of a dedicated infusion clinic for acute management of adults with sickle cell pain crisis. Am J Hematol. 2015. serial onlinehttp:// dx.doi.org/10.1002/ajh.23961

35. Benjamin LJ, Swinson GI, Nagel RL. Sickle cell anemia day hospital: an approach for the management of uncomplicated painful crises. Blood. 2000; 95:1130-1136. serial online. [PubMed: $10666181]$

36. Adewoye AH, Nolan V, McMahon L, et al. Effectiveness of a dedicated day hospital for management of acute sickle cell pain. Haematologica. 2007; 92:854-855. serial online. http:// dx.doi.org/10.3324/haematol.10757. [PubMed: 17550862]

37. Koch KL, Karafin MS, Simpson P, et al. Intensive management of high-utilizing adults with sickle cell disease lowers admissions. Am J Hematol. 2015; 90:215-219. serial online. http://dx.doi.org/ 10.1002/ajh.23912. [PubMed: 25469750] 
38. Andemariam B, Owarish-Gross J, Grady J, et al. Identification of risk factors for an unsuccessful transition from pediatric to adult sickle cell disease care. Pediatr Blood Cancer. 2014; 61:697-701. serial online. http://dx.doi.org/10.1002/pbc.24870. [PubMed: 24347402] 


\section{Table 1}

Focus Group Facilitator Guide

\begin{tabular}{|l|l|}
\hline Question & Probes \\
\hline $\begin{array}{l}\text { "Let's start the discussion by talking about your experience of moving } \\
\text { from pediatric to adult care. What was your experience like?" }\end{array}$ & $\begin{array}{l}\text { What was your experience in leaving pediatric care? } \\
\text { How was your first visit to the adult clinic? The adult ED? The } \\
\text { adult inpatient unit? }\end{array}$ \\
\hline $\begin{array}{l}\text { "Tell me about a time you felt you were in charge of your own health } \\
\text { prepared you to do that?" }\end{array}$ & $\begin{array}{l}\text { Did you have any specific transition preparation? } \\
\text { What factors helped prepare you to take on a more adult role in } \\
\text { terms of your health care? In other aspects of your life? }\end{array}$ \\
\hline $\begin{array}{l}\text { "What if there was a specific program to help patients move from } \\
\text { pediatric to adult care. What would you like to see in such a program?" }\end{array}$ & $\begin{array}{l}\text { If you had transition preparation, what specifically helped you? } \\
\text { What was missing that would have helped? }\end{array}$ \\
\hline $\begin{array}{l}\text { "Let's talk about how to help young adults make a 'successful' transition } \\
\text { from pediatric to adult care. How would you define a successful } \\
\text { transition?" }\end{array}$ & $\begin{array}{l}\text { Is it something we can measure? A feeling? } \\
\text { Does it have more to do with the specific doctor or clinic, or } \\
\text { something outside of the medical system? }\end{array}$ \\
\hline $\begin{array}{l}\text { "Let's talk about your advice for teenagers or other young adults still } \\
\text { planning their move from pediatric to adult care? What would you tell } \\
\text { them?" }\end{array}$ & $\begin{array}{l}\text { Are there things you wish you had known? } \\
\text { What advice would help make the transition easier? More } \\
\text { successful? }\end{array}$ \\
\hline
\end{tabular}


Table 2

Focus Group Participant Characteristics and Survey Responses

\begin{tabular}{|c|c|}
\hline & Results (n=15) \\
\hline Gender $\mathrm{n}(\%)$ & Female $8(53 \%)$ \\
\hline Self-reported race n $(\%)$ & $\begin{array}{l}\text { Black/African American } 9(69 \%) \\
\text { Haitian } 2(15 \%) \\
\text { Hispanic or Latino } 2(15 \%)\end{array}$ \\
\hline Highest level of education $\mathrm{n}(\%)$ & $\begin{array}{l}\text { Some high school } 1(8 \%) \\
\text { High school graduate } 2(15 \%) \\
\text { Some college/2-year degree } 6(46 \%) \\
\text { 4-year college degree } 4(31 \%)\end{array}$ \\
\hline Age mean; SD (range) & $24 ; 2.6(18-28)$ \\
\hline Age at leaving pediatric hematology care mean; SD (range) & $21 ; 1.8(18-24)$ \\
\hline Hospital where pediatric care was received $\mathrm{n}(\%)$ & $\begin{array}{l}\text { BMC } 12(80 \%) \\
\text { CHB } 2(13 \%) \\
\text { Both BMC and CHB } 1(7 \%)\end{array}$ \\
\hline $\begin{array}{l}\text { Preparation for first adult visit } \mathrm{n}(\%)^{*} \\
* \text { Numbers add up to }>100 \% \text { because some patients received multiple methods of preparation }\end{array}$ & $\begin{array}{l}\text { Not prepared } 3(23 \%) \\
\text { Discussed with pediatric hematologist } 7(47 \%) \\
\text { Discussed with social worker } 3(20 \%) \\
\text { Attended transition clinic } 3(20 \%)\end{array}$ \\
\hline
\end{tabular}

